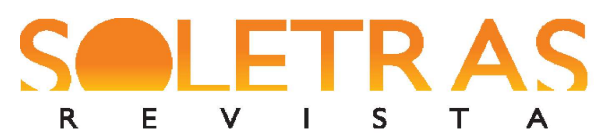

DOSSIÊ-N. 35 - 2018.1 - ANABEL GUTIERREZ ASSIA SLIMANI-ROLLS CHRIS ROWELL

\title{
Assessment as a learning process: the use of Exploratory Practice to empower students and to foster teacher development
}

\author{
Anabel Gutierrez ${ }^{1}$ \\ Assia Slimani-Rolls ${ }^{2}$ \\ Chris Rowell $^{3}$ \\ Regent's University London
}

\begin{abstract}
The purpose of this paper is twofold: on the one hand, it presents a yearlong study (20162017) that reports on the design and implementation of a module assessment through a peer review process (BOSTOCK, 2000; TOPPING 2000; FALCHIKOV, 2005) Using Turnitin, which is a commercial, Internet-Based Plagiarism-Detection Service. The peer review aims to help the students to understand the marking criteria and standards, which are focused on the development of research skills and encourage them to take control of their learning. The peer review processes represent the formative feedback that students give to each other to enable them to achieve the required standard that their work must ultimately reach prior to its final submission. On the other hand, the paper also highlights the professional development issues that emerged as a consequence of adopting the principled framework of Exploratory Practice (EP) (ALLWRIGHT, 2003, 2005; GIEVE \& MILLER, 2006; ALLWRIGHT \& HANKS, 2009), which allowed the teacher and the students to work for a better quality of life, as they enhanced their understandings of what they were trying to achieve together in the classroom. A number of benefits have been identified as a result of this investigation. The students gained a better grasp of the literature review process, heightened their motivation to learn about the topics that they need to investigate, engaged more deeply students' engagement during lectures, and developed a sense of ownership of their learning. The teacher herself voices her reflection about the perceived benefits gained from working collaboratively with students and with experts in related fields and finds that the process has generated insights that have transformed her teaching in various ways.
\end{abstract}

Keywords: Exploratory Practice. Teacher professional development. Formative assessment. Peer review. Self-regulated learners

\footnotetext{
${ }^{1}$ Principal Lecturer in Digital Marketing and Innovation at Regent's University London. She is a Fellow of the Higher Education Academy with over 25 years of academic, which she has balanced her with industry practice gained from consultancy work in IT projects for both private and public sector. Her research interest areas are in innovation and adoption of emerging technologies for the digital economy with particular interest on data privacy concerns, the use of data to understand consumer behaviour and how to improve data-driven decisionmaking.

${ }^{2}$ Reader (Associate Professor) of Applied Linguistics and Education. She is Head of Research and Professional Development at Regent's University London. Her research interests lie in inclusive practitioner research, teacher learning, adult second language acquisition in a multilingual context.

${ }^{3}$ Academic Developer in Digital Enhanced Learning at London South Bank University. Previously he was Deputy Learning Technology Manager at Regent's University London (2010-2017), a Lecturer in Economics (1990-2005) and a Lecturer in Education (2005-2010) at University Centre Croydon. He was also a member of SEDA's Conference Committee and SEDA's Special Interest Group on Technology-Enhanced Practice. Currently, he is an editor of ALT's blog.
} 


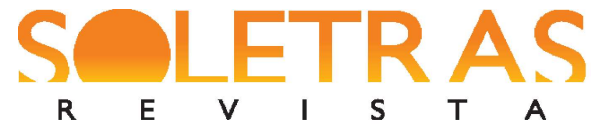

DOSSIÊ-N. 35 - 2018.1 - ANABEL GUTIERREZ ASSIA SLIMANI-ROLLS CHRIS ROWELL

\section{Introduction}

There has been an emphasis on student centred learning in higher education, which essentially encourages students to take responsibility for their learning and personal involvement in classroom activities as opposed to the teacher's control over and transmission of academic content as is found in conventional teaching (BREEN \& LITTLEJOHN 2001; TRIGWELL, PROSSER \& WATERHOUSE, 1999). One of the implications of this perspective is that students actively construct their own knowledge and are empowered to self-regulate their learning processes (FRY, KETTERIDGE \& MARSHALL, 2009). Formative assessment and feedback are mechanisms, which are put forward to help students to engage in this self-regulation, which requires them to understand the goals and standard that need to be achieved (NICOL \& MACFARLANE-DICK, 2006). Self-assessment is a prerequisite for effective learning and feedback constitutes a bridge between the student's performance and standard to be realised (BLACK \& WILLIAM, 1998). It is not enough to tell students what they should do. If they are to become knowledgeable and performing in their subject discipline, they must be involved in relevant aspects of their own assessment and that of their peers to enhance their learning and capacity to assess the quality of what is produced by themselves and by others in their areas of development. Only then students begin to understand and share the tutor's conception of the subject andadapt theirwork accordingly. As Sadler (1989) explains, students must find out about the standards to be achieved; compare their work to the intended goals and subsequently take action to reduce the gap between the feedback and the next assignments. In our study, the learners that were engaged in the peer review process had to work towards producing a paper in English bearing in mind the standards they had to reach before submitting the final version of their research.

A number of studies have cast light on the benefits of peer review (BOSTOCK, 2000; TOPPING, 2000; FALCHIKOV 2005); its value in assisting the learning process (BIGGS \& TANG, 2011); and its impact on increasing students' levels of motivation, responsibility and accountability towards their work. Opening opportunities for students to gauge the degree to which they have, or otherwise, met the criteria helps them to develop important skills for lifelong learning (BOUD, 2000), such as evaluating their own work, providing feedback, arguing a viewpoint and developing negotiation skills. In this respect, Stefani (1998, p.346) contends that "if assessment processes are intended to enhance student

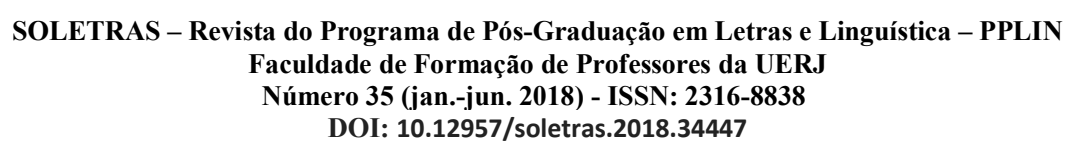




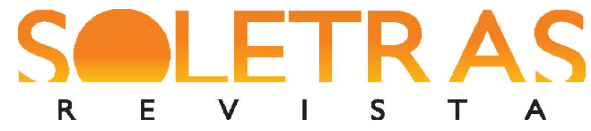

DOSSIÊ-N. 35 - 2018.1 - ANABEL GUTIERREZ ASSIA SLIMANI-ROLLS CHRIS ROWELL

learning then it follows that students must be enabled to reflect on their current attainment "and that of their peers. Moreover, reporting on a study they conducted with secondary school teachers, William et al. (2003) assert that peer assessment enables students to grow the necessary objectivity and open-mindedness for self-assessment leading them to direct their own work and become independent learners. They conclude that peer and self-assessment "made unique contribution to the development of students' learning - they secure aims that cannot be achieved in any other way" (WILLIAM et al., 2003, p. 53).

Going beyond student learning and development, we would like to highlight here the parallel teacher development process that was generated as the teacher worked with her students. It is worthwhile reflecting upon why, in many cases, as teachers or even as teacher educators, we tend to focus only on the development of our students' or future teachers' knowledge, skills and performance, but mostly tend to ignore that learning opportunities are being created for everybody, including us. Reflexively, we could say that in the writing of this paper, we became more aware of our own professional development.

\section{Background of the Study}

Prior to going any further, it is important to note that this study has been undertaken in order to meet the requirements of the University which provides every staff with up to 100 hours of time abatement to enhance their continuing professional development and keep up with the research and scholarship of their subject discipline. Hence the development of this study helped Anabel Gutierrez, the teacher, to develop a better understanding of handling the "Emerging Technologies for Business" module that is taken by the second year students on the BA International Business (HONS) programme. This module runs every term over 12 weeks with 3 hours contact each week in a UK University in London. This module provides students with a comprehensive overview of trending technologies that are reshaping the way organisations work in the digital economy. The module has two main learning objectives:

(i) to help students understand the key emerging technology concepts, with a focus on the information management theory, which is presented in a one-hour lecture per week; and

(ii) to develop practical analytical skills using software for data analysis which is presented in a two-hour lab session per week. 


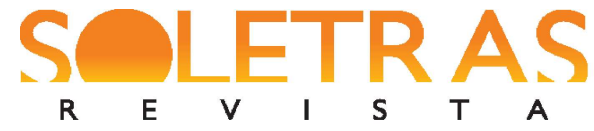

DOSSIÊ-N. 35 - 2018.1 - ANABEL GUTIERREZ ASSIA SLIMANI-ROLLS CHRIS ROWELL

The module assessment strategy is aligned with these two objectives and includes two types of assessments. Assessment One, which consists of an individual research report, and Assessment Two, which consists of a group project report. Each assessment is worth 50\% of the total module mark. This study is concerned with the assessment strategy that is related to the individual research report (Assignment One) for which students are required to conduct an in-depth research on key ICT technologies studied in class such as cloud computing, blockchain, big data analytics, social media and the Internet of Things. Students must propose their own research question or address a specific research question suggested by Anabel whose classroom is the object of inquiry. Some of Anabel's questions are illustrated below:

- How can Blockchain technology be used to enhance supply chain management?

- How does Instagram influence consumer perspective in the fashion industry?

- What are the drivers that influence consumers' acceptance of the Internet of Things within the retail industry?

- What effect will Virtual Reality have in the Healthcare industry?

- How is Big Data used in mobile marketing?

As a result, each student has a specific research question that is linked to one of the key topics of the module including a specific perspective that the student is interested in. This individual research report enables the students to gain a deep understanding of the selected technology while, at the same time, developing research skills such as searching and evaluating the quality of a range of sources of information, using on-line databases, writing critical literature reviews in English, bearing in mind the constraints of the genre, with a clear focus on the main research question. This assessment also provides students with opportunities to assess their theoretical grasp of the subject and ability to employ these skills in order to articulate their ideas and newly acquired knowledge through the development of a 2000 word written report. However, in spite of the explanations and demonstrations that are given in class, many of the students do not raise to the demands of this assessment. The following are only some of the issues which prevent the participants to benefit from each other's efforts and from establishing a good quality of classroom life.

- Many of the international and exchange students are unfamiliar with this type of assessment and as yet, do not seem to understand the marking criteria.

- Students do not possess the research skills required for the development of this assessment. They are unable to evaluate the quality of their research sources, the evidence

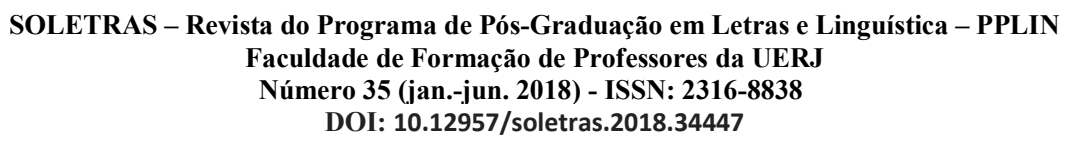




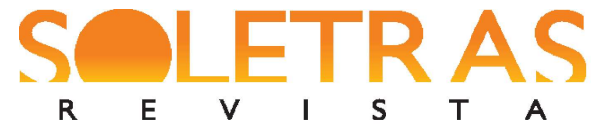

DOSSIÊ-N. 35 - 2018.1 - ANABEL GUTIERREZ ASSIA SLIMANI-ROLLS CHRIS ROWELL

they provide for their arguments and the clarity of their ideas. Academics usually assume that students know how to conduct a literature review but this is not the case in practice.

- Students frequently relegate their assignment to the last minute resulting in poor quality, rushed arguments, and low marks, which makes handing the marked report back to the students a painful experience for both parties- the teacher and the learners.

- Students normally receive detailed feedback with their final marks. In most cases, however, this feedback is ignored because, at this stage, students are more concerned with the mark than the feedback and complain that they cannot understand why they have not been able to achieve the grade they expected after so much work.

- The report is submitted, marked and handed to the students without providing them with the possibility of repairing it; thus rendering futile the teacher's time-consuming task of giving them generous and constructive feedback.

- The marking process became a nuisance. Instead of being an informative reading exercise enabling to adjust teaching to potentially further learner development, it became a dreaded and daunting task for the teacher and had a negative impact on the students' grades and motivation.

Figure 1 below summarises the organisation of the module assessment strategy and positions Assessment One (individual research report) as being submitted in week six and handed back to the students in week 8 with no possibility of repairing it as indicated by the students who then turn their attention to the development of Assessment Two (group report).

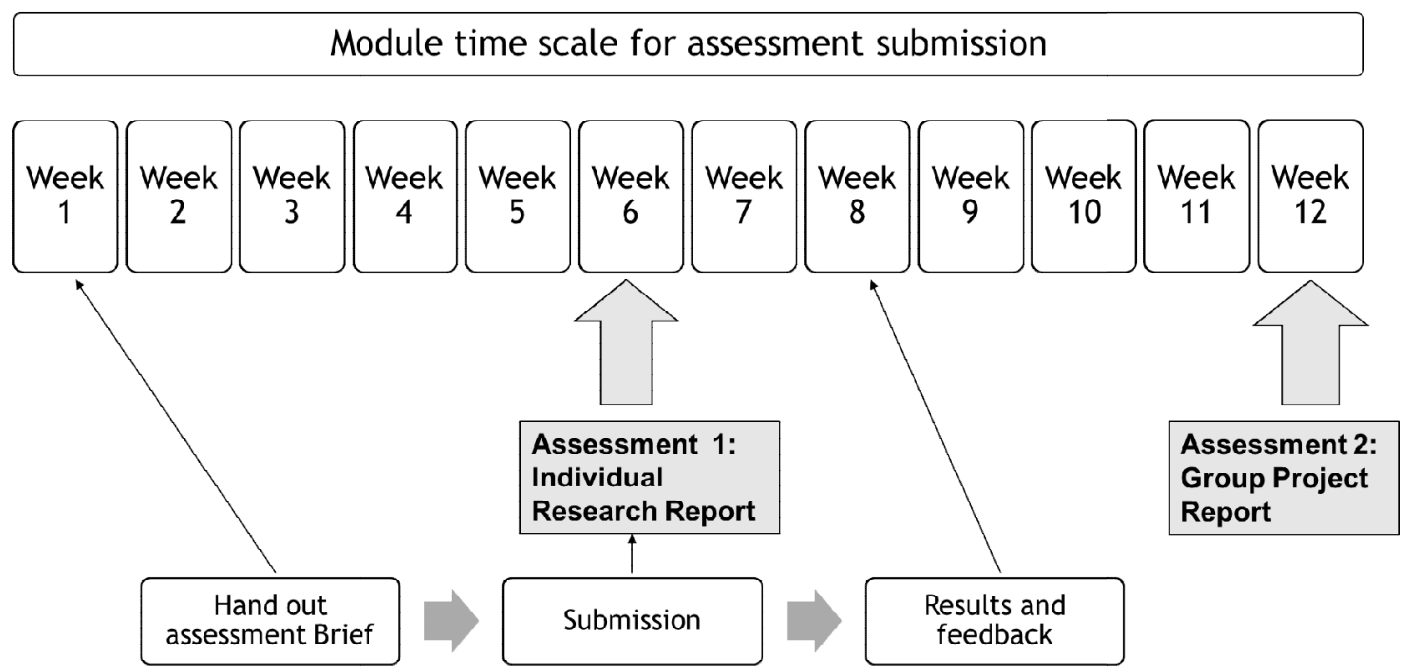

Figure1. Initial assessment time scale for the module 


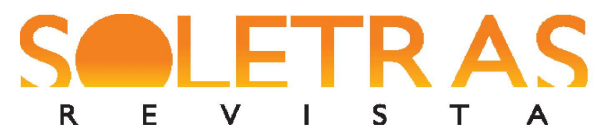

DOSSIÊ-N. 35 - 2018.1 - ANABEL GUTIERREZ ASSIA SLIMANI-ROLLS CHRIS ROWELL

\section{Exploratory Practice (EP): The Research context}

To address the issues related above, the principles of Exploratory Practice (EP) were used to enable me to understand why the students could not apply themselves to produce better reports. At this point, we shall introduce the reader to Exploratory Practice, which is a form of practitioner research developed in the 1990s (ALLWRIGHT \& BAILEY, 1991; ALLWRIGHT \& LENZUEN 1997) to empower teachers and learners to work alongside each other in order to develop a better understanding of their classroom practice. Although EP has been initially developed for language education (ALLWRIGHT 2003, 2005; GIEVE \& MILLER, 2006; ALLWRIGHT \& HANKS, 2009), EP has also been used for other taught subjects as Slimani-Rolls and Kiely (2014) have demonstrated with teachers and students in Law and Management Studies in higher education.

Several principles make up the theoretical and reflective framework of EP whose aim is to guide the search for understanding the teachers' (and learners') concerns that they may have about their classroom environment and which prevent them from benefiting from the efforts that each party produces towards the development of a thriving learning and teaching environment. EP's guiding principles are as follow:

1. 'Quality of life' for language teachers and learners is the most appropriate central concern for practitioner research in our field.

2. Working primarily to understand the 'quality of life', as it is experienced by language learners and teachers, is more important than, and logically prior to, seeking in any way to improve it.

3. Everybody needs to be involved in the work for understanding.

4. The work needs to serve to bring people together.

5. The work needs to be conducted in a spirit of mutual development.

6. Working for understanding is necessarily a continuous enterprise.

7. Integrating the work for understanding fully into existing curricular practices is a way of minimizing the burden and maximizing sustainability.

(ALLWRIGHT \& HANKS, 2009, p. 149-154)

Principles 1 and 2 highlight the relevance of the socio-emotional climate that needs to be taken into consideration in order to enable all participants to feel emotionally 


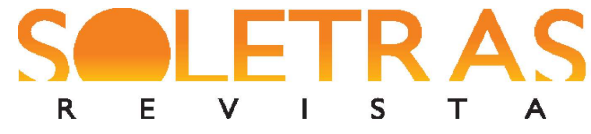

DOSSIÊ-N. 35 - 2018.1 - ANABEL GUTIERREZ ASSIA SLIMANI-ROLLS CHRIS ROWELL

comfortable and remain focussed on and interested in the learning experiences that are being developed by the classroom participants. In other words, EP claims that it is the attention that is paid to developing quality of life in the classroom that paves the way to the development of quality of work (GIEVE \& MILLER, 2006). Principles 3, 4 and 5 cast light on the multitude of possibilities offered by the people who inhabit the learning and teaching environment in which the teacher and the students would evolve. These principles bring together collegiality amongst colleagues whose expertise could contribute to the investigation of teaching concerns as well as the inclusion of the learner as a collaborative partner in the search for understanding these concerns. This way the outcomes of the investigative efforts benefit equally all those involved in the research enterprise. Principles 5 and 6 recommend investing research efforts throughout the participants' lives in the classroom to make research continuous and sustainable by integrating it into teaching so that research becomes part of teaching and not extra to it (ALLWRIGHT 2003). As pointed out by Slimani-Rolls and Kiely (forthcoming, p.10), "Indeed, teachers need to have the support of a teacher development framework, which guides the analysis of existing practice, and the shaping of new activities and routines for the classroom".

This is exactly what happened in the research being presented here as it can be seen in the fragments of a paper written by Anabel, the teacher and one of the writers of the present article. The collaborative teaching experience lived by the teacher and her students was also a collaborative research experience lived by the teacher and two other professionals at the university. Both very fruitful for the practitioners involved.

As a teacher, and in my attempt to integrate my search for understanding my classroom situation, I attempted to work more closely with the students as partners in my teaching endeavour by trying to address their lacks and priorities. In order to reach this aim Icalled upon the cooperation of colleagues from my university: a researcher in teachers' professional development, Assia Slimani-Rolls, to help me with the understanding of EP in my context and the development of interpretative skillsto make sense of the classroom events. Given the nature of the module, I also invited the learning technologist, Chris Rowell, to advise me on the effective use oftechnological devicesthat could facilitate the students' task of producingrelevant reports to consolidate their learning andto enhance their quality of life and that of the teacher. 


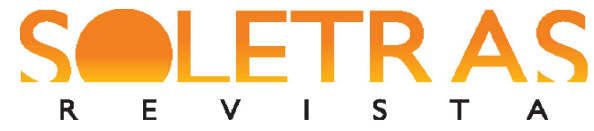

DOSSIÊ-N. 35 - 2018.1 - ANABEL GUTIERREZ ASSIA SLIMANI-ROLLS CHRIS ROWELL

Thus, Anabel, the teacher, profited from this research situation to deepen her knowlegde on/about teaching and learning, on/aboutthe quality of life in her classroom. It is worth emphasizing how she positioned the learners as partners - they were not research subjects. In addition to this, she asked for her colleagues' help in order to focus on a research project that met her interests. Both colleagues were not outsiders who came into her class to generate data that would fit their research interests. Some of Annabel's understandings can be mapped in the fragments below:

The researcher suggested that I recorded some of my teaching sessions to observe more closely my teaching behaviour and the classroom interaction during my lessons. To my surprise, it did not take more than one recording to notice that my teaching was more transmissive than collaborative, as I normally assert it is. I observed myself lecturing on the skills that I wished the students to develop while, at the same time, I gave priority to time pressure and my own agenda in order to cover planned syllabus items. Hence, I assumed that providing the students with further readings and tasks to carry out outside the classroom would help them acquire the skills and knowledge that I had expounded during the class. I realised that, in several cases, I did not create opportunities for them to actually practice and discuss with their peers, in contexts that they recognise, the criteria and standards that I presented in class. Following a discussion with my colleague, Assia, we decided that teaching activities should be focussed on enabling the students to carry out selfassessment in order to improve their understanding of their own ability and performance. Secondly, they should be provided with opportunities to work collaboratively with their peers to carry out peer assessment of the reports. At this stage, the learning technologist recommended the use of Turnitin to allow the management of the students' submissions and randomly distributed anonymised research reports to each peer. The Turnitin device allowed me, as the lecturer, to customise the number of papers a student could realistically receive and supply a prompt and timely feedback.

The rest of the paper reports on how the peer review, which has been developed collegially by the teacher, the colleague with EP expertise and the learning technologist was incorporated as an assessment learning process, to enable the students to understand the aims of the individual report and how to execute effectively its requirements. Above all, students have been provided with variety and choice in the exercises that they would like to undertake for practice. This review was improved over two teaching terms, between 2016 and 2017, and currently routinely implemented with the students. 


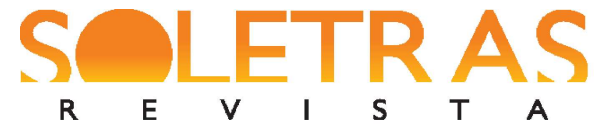

DOSSIÊ-N. 35 - 2018.1 - ANABEL GUTIERREZ ASSIA SLIMANI-ROLLS CHRIS ROWELL

Implementation of peer review process to support the understanding of the criteria and standards

In this section, we use the teacher's report on the implementation of peer review process. We highlight the decision making process regarding activity design and the teaching objectives that underpinned each of them. It is worth pointing her care for the students since she really wanted to help them overcome the difficulties she had identified.

I cut down on the time allocated to lectures and ran a series of hands on activities for students to work individually and collaboratively in class to familiarise themselves with the criteria and standards of the assessment so they are well equipped to tackle the individual report.This process provided me with extra time to walk around the groups and ensures timely feedback and guidance. Although additional feedback activities have been incorporated in order to help students to understand the assessment requirements, this did not necessarily add extra workload to the students as the teaching activities aimed to enhance their knowledge to meet the module assessment strategy as a whole including assessment one. The implementation of the peer review was tried out and enhanced over two teaching terms and included the following key aspects:

1. To introduce self and peer assessment, the students worked together with the teacher to establish and subsequently apply criteria and standards to tasks that they had performed. Then they awarded marks to themselves with reference to each criterion. To help them focus on this task, they reflected on questions such as "how to distinguish good from inadequate work?" and "what would characterise a good assignment in our course"? The purpose for this was to highlight the relationship between the criteria that we established together, the provision of clear evidence and self-evaluation; thus allowing them to make balanced judgements and realistic evaluations of the quality of what has been achieved. Ironically, some students reported that some teachers provided a grade only. Hence, I asked them to add a statement to justify the overall assigned grade. Once their tasks were completed, the students exchanged their work with their peers to contrast their own mark with the one given to them by a peer bearing in mind the criteria and the standard that we had discussed. Hence opportunities for students have been created to involve them in establishing the criteria and standards they will apply to their work and that of their peers and then made the judgements about the degree to which they have been met.

2. Opportunities were created for students to use an on-line library as well as various databases to search for information related to their research question as well as bibliography and referencing system. This activity was led by the assessment brief which stated that "Research should be focused and relevant to the research question; both descriptive and analytical and supported by theoretical concepts; wide range of sources and correct referencing used" and allowing them to understand the quality of different sources of 


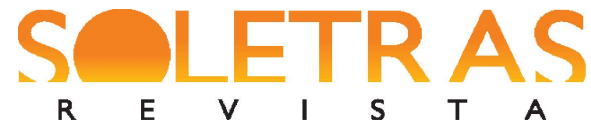

DOSSIÊ-N. 35 - 2018.1 - ANABEL GUTIERREZ ASSIA SLIMANI-ROLLS CHRIS ROWELL

information to use in their report. In this exercise, the students were quick to alert their peers to other sources of information and the details of the type of reference style that is recommended by the course that some have not yet mastered. Students were also given the chance to peer assess the content, structure and writing style of tasks and have shown dexterity in raising each other's attention to the variety of content and adequacy, or otherwise, of the structure and writing style with a focus on criteria and provision of clear evidence and explanation.

3. Following this series of collaborative work, the students had submitted their anonymised individual reports in week 6 through Turnitin, which forwarded them anonymously to the peers. With the learning technologist's support, I set up specific questions, which are linked to the marking criteria and used as prompts for the students to ensure that the peer's report contained appropriate information, content, structure, writing style and reference system that targeted the intended standards.

Once peer-assessed, I reviewed the reports and feedback that the students supplied to each other. I noted that some students had pointed out areas of improvement to their peers, which I would not have been able to identify had I read all the reports by myself. Subsequently, I summarised the recurrent problems identified by the students and also by myself and reported them on some slides for the students to discuss in dyads and triads while I walked around the groups ensuring that the highlighted issues were understood. This operation was carried out because first, it was important to confirm the information that the students had received, and secondly to emphasise to them that peer-assessment is an integral part of the learning process and as such should not be perceived "as a soft option or abdication of responsibility" (Race 1999: 173)on the part of the teacher as some students tend to think as we shall see below.

These initiatives were quite challenging in terms of timescale but the date of the final submission was extended to allow extra days for the students to accommodate the formative assessment and allow time for the students to repair their work before final submission in week 8 (rather than 6) thus actually demonstrating that assessment is used as learning and for learning as recommended in the literature. The use of Turnitin has been very useful not only to manage the peer review process but also to speed up the feedback provision as all the participants- the students and myself - became more experienced in processing it with this tool.

The teacher's care, however, did not mean the students would not be responsible for producing and handing in the assigned papers. Also, the teacher used different opportunities in the course to make the students read and produce texts, engage in face-to-face interaction that made them use the kind of language and the information needed to produce the final reports - 'to add a statement to justify the overall assigned grade', 'use an on-line library as well as various databases to search for information related to their research question as well as bibliography and referencing system'. 


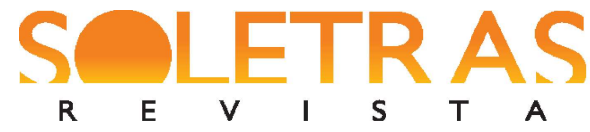

DOSSIÊ-N. 35 - 2018.1 - ANABEL GUTIERREZ ASSIA SLIMANI-ROLLS CHRIS ROWELL

See below Figure 2, which summarises the review of the assignment to introduce formative assessment in multiple stages and extend the date of its final submission.

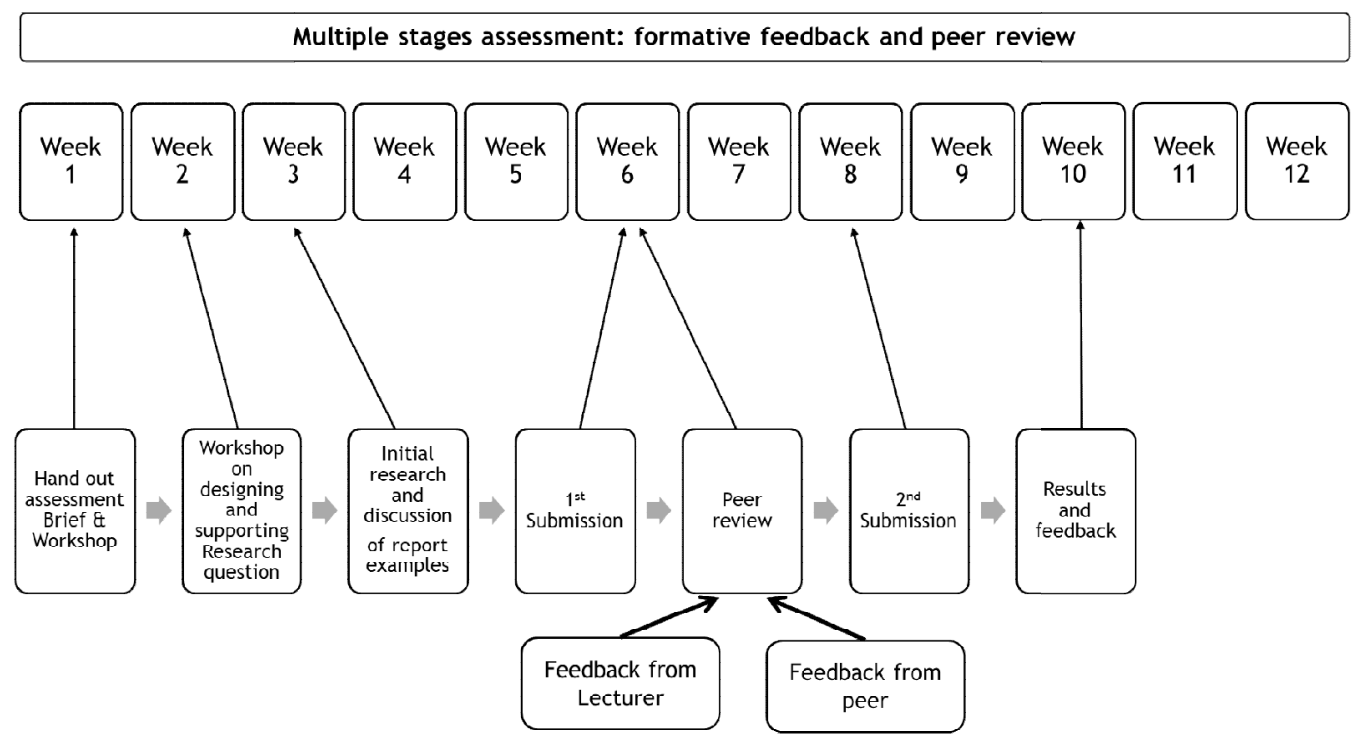

Figure 2. Multiple stage assessment time scale

The following section describes how the key elements of the assessment process were perceived as well as highlights the benefits, caveats, and lessons learned from the implementation of the peer review process as multistage assessment.

\section{Benefits for the students and the teacher}

The re-design of the assessment produced positive results that were observed by the teacher and reported by the students in a class discussion that they had following the results and feedback in week ten. The key aspects are:

- The overall quality of the research reports improved. The students understood better how to conduct a critical literature review. As expressed by the students when asked if the peer review had helped them to improve their grade.

"Yes. Applying critical thinking and critical evaluation to somebody else's work helps to apply the same skills to your own work and also improves the speed of thinking."

- The students also enhanced their research and writing skills in terms of better argumentation with relevant references and accurate referencing style, which helped them 


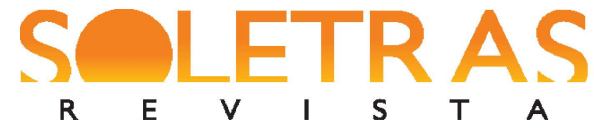

DOSSIÊ-N. 35 - 2018.1 - ANABEL GUTIERREZ ASSIA SLIMANI-ROLLS CHRIS ROWELL

with Assessment One and, just as importantly, represents transferable skills that students will use in Assessment Two and other assessments including their end of year degree dissertation. The writing process allowed the students to crystallise their thinking, and as a result, they were more confident in the development of well thought out arguments for their reports.

- The extension of the submission report from week 6 to week 8 provided some more time for the international and exchange students to make sense of the assignment strategy.

- The peer review process increased the students' engagement. Students were able to connect their extra readings to the topics covered by the lectures allowing them to engage in discussion, which motivated them to learn more about the topic to make their research statements much deeper than usual as revealed by the following student:

“... Different students have focused on different aspects of information systems and it was useful to read it in a report form and read various arguments. Also placing yourself on the other side of the table helps to change the perspective." Learner idiosyncrasy

- After this collaborative process, the students' engagement was more evident as they claimed to have learned not only from the lecturer but also from their classmates as recognises the following student;

"As part of the learning process, this cooperation helped me to develop new skills. Learning from colleagues is equally important as learning from the teacher."

- Students showed more responsibility for their learning following this peer review process. There were fewer complaints about the fairness of the marks because the students understood better the marking criteria. In some cases, some students have requested to discuss their assessment, but they were more focused on how to improve their critical thinking rather than discuss their final grades.

- The multistage approach helped students to distribute their effort more evenly across weeks and attendance to the lectures improved.

The above marked enhancement in the students' behaviours and attitudes made the teacher feel more confident and accomplished as a teacher as she could see that their inclusivity in the research process enabled them to develop trust towards each other and take more responsibility for their own learning (MILLER, 2009). Indeed, EP ensures that all participants have a role to play in the classroom, which becomes a space for learning and enhancing the capacity for learning. Moreover, the research process added to the teacher's

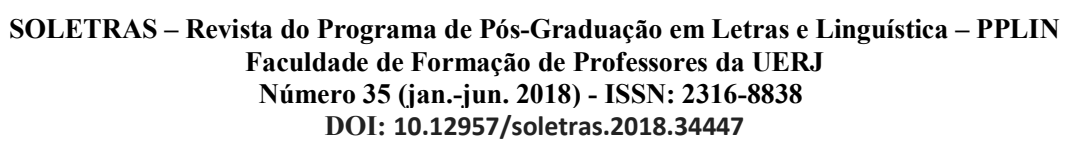




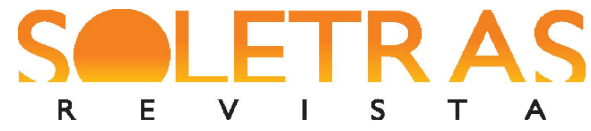

DOSSIÊ-N. 35 - 2018.1 - ANABEL GUTIERREZ ASSIA SLIMANI-ROLLS CHRIS ROWELL

development more reflexivity, the construction of a careful look at the students' behaviours and attitudes, which made her fine tune her classes to their actual needs. Although the teacher was not engaged in a formal program for teacher development or in-service teacher education, she recognized how research practices, and, in her case, the help of colleagues can pave the way for her professional development.

\section{Lessons learned}

The feedback process can be time-consuming for the lecturers as well as the students. Its implementation requires each activity to be carefully tailored to the specific module environment (subject, level, number of students, etc.) in order to enable students to provide quality feedback in a timely manner without overloading them. Their response to whether they would recommend the use of peer review to other lecturers, students and modules were mainly positive, although, the time element was given some consideration:

"I think it's a good balance of things; it teaches students to practice critical thinking and it allows students to gain perspective when assessing their own work and that of the classmates. But time is required and the module must allow time for this activity because it is useful."

The implementation of the peer review moderation requires lecturers to closely monitor students' progress to ensure that all of them receive useful feedback that they can be used to improve their work. Some students provided good insight when asked if the peer review has helped them:

"Yes but it works only if each student puts the same effort. It is unfair for students to put a detailed peer review together and not receive the same feedback."

"It depends on the seriousness of the peer reviewer one gets. Personally, I benefitted much from my peer review as I got a lot of helpful and constructive feedback, which helped me to improve my report and added insight to it. "

"Ideally yes but it really depends on the quality of feedback received from the student who did the peer review. Some students put a lot more effort than others."

A possible way of addressing this issue is to offer students the opportunity to discuss the feedback they receive from their peers and emphasise the need for joint responsibility towards highquality learning fostered not only by the teacher but also by the learners who must show honesty, 


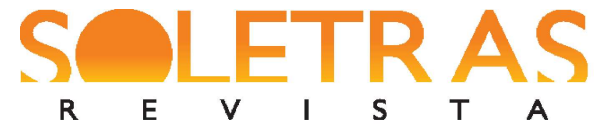

integrity and involvement in the class activities for the benefit of all. Research has shown that students can learn from their peers (SLIMANI 1992) and peer feedback may be more helpful in some way than teacher feedback. Blackwell et al. (2003, p. 77) reported that peer feedback is not as 'emotionally loaded', when provided by the teacher. Moreover, the language used by peers may be easier for students to understand (BLOXHAM \&WEST, 2004) and therefore benefit from it.

Additionally, resistance to change the traditional student-teacher relationship has to be taken into consideration. There is some resistance from some students to engage with the peer review, as they believe that it is the lecturer's responsibility; the only one with the authority and knowledge to provide quality feedback.

“... we are here to learn from the module leader and need constructive yet critical feedback from them more so than from our peers."

In this respect, and considering the teacher's report above, it is quite clearer that she learned much from the students. It is their reactions to her interactions in the classroom, which made her realise that her ways of conveying teaching needed to be adjusted to facilitate the students' learning. It appears that students take it for granted that learning is unidirectional and necessarily going from the teacher to the learners. In actual fact, many of the studies mentioned in this article have found that much learning can also happen as a result of students' action as experienced in this study by the teacher when reviewing the students' feedback and by some of the students when being peer-assessed. However, she needed to realise that these observations must be shared and discussed with the students, so they can begin to listen to and trust each other as competent people "capable of taking learning seriously" (ALLWRIGHT \& HANKS, 2009).

\section{Conclusion}

Reviewing the whole experience, it can be asserted that Exploratory Practice transformed the way the teacher viewed the students in the classroom. Although she was making efforts to engage students in class, self-observation showed her that she considered them as passive recipients accepting and internalising her expert knowledge the way she expounded it during her teaching. However, as she took time to observe her teaching and analysing, together with the other researcher, their reaction to it made her realise that she needed to listen to them (RAMSDEN, 2003) in order to understand how her instruction can be of benefit to them. It is not only students who need to act on feedback. For assessment to be

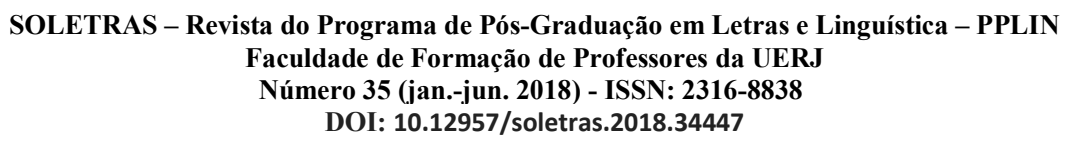




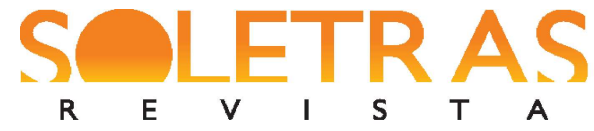

DOSSIÊ-N. 35 - 2018.1 - ANABEL GUTIERREZ ASSIA SLIMANI-ROLLS CHRIS ROWELL

effective in a formative way that enhances students' future learning, the feedback, albeit produced indirectly as a reaction to her teaching in the classroom, should be used to adjust the teaching which she had done in this study. Reviewing the components of one assessment following the principles of Exploratory Practice has not only benefitted the students but has benefitted her too. It has allowed her to revitalise the way she views her surroundings and make the most of them in order to transform the quality of the classroom for all concerned. The assessment strategy of the module was transformed with the potential implication of student skills transfer to other part of their development on the programme. Adding to this, her understandings of the learners' needs inspired her to develop far more collaborative opportunities for students as they each bring different experiences to the interaction they have with each other. Ultimately, we use the teacher's evaluative comments on the role EP played in her professional development:

\footnotetext{
EP has also contributed to widening effectively the network of expertise that I can access in my direct working environment. Indeed I have particularly benefitted from being involved in collaborative work with experienced colleagues who enabled me to develop an enquiry mode towards my teaching and gave me the confidence to tackle particular technologies that are necessary to my everyday life in the classroom.
}

\section{References}

ALLWRIGHT, D.; HANKS, J. The developing language learner: An introduction to Exploratory Practice. Basingstoke, UK: Palgrave Macmillan, 2009.

ALLWRIGHT, D. Exploratory Practice: Rethinking practitioner research in language teaching. Language Teaching Research, 7(2), 2003, p. 113-141.

ALLWRIGHT, D. \& LENZUEN, R. Exploratory Practice: Work at the Cultura Inglesa, Rio de Janeiro, Brasil. Language teaching Research, 1(1), 1997, p.73-79.

ALLWRIGHT, D.; \& BAILEY, K.M. Focus on the language classroom. An introduction to classroom research for language teachers. Cambridge University Press. Cambridge, New York. Port Chester, 1991.

BIGGS, J. \& TANG, C. Teaching for Quality Learning At University (Society for Research Into Higher Education). Glasgow: Bell and Bain Ltd., 2011. 


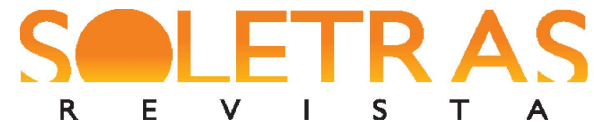

DOSSIÊ-N. 35 - 2018.1 - ANABEL GUTIERREZ ASSIA SLIMANI-ROLLS CHRIS ROWELL

BLACK, P. \& WILLIAM, D. Assessment and classroom learning, Assessment in Education, 5 (1), 1998, p. 7-74.

BLACK, P., HARRISON, C., LEE, C., MARSHALL, B. \& WILLIAM, D. Assessment for Learning: Putting It into Practice. Maidenhead: Open University Press, 2003.

BLOXHAM S. \& WEST, A. Understanding the rules of the game: marking peer assessment as a medium for developing students' conceptions of assessment. Assessment \& Evaluation in Higher Education, 29(6), 2004, 721-733.

BOUD, D. Sustainable assessment: rethinking assessment for the learning society, Studies in Continuing Education, 22(2), 2000, 151-67.

GIBBS, G., Using assessment to support student learning. Leeds Metropolitan University, 2010, 1-52. Available at: <https://workspace.imperial.ac.uk/edudev/Public/Additional_ Feedback_Reading_Mobile.pdf $>$

GIEVE, S. \& MILLER, I. K (Eds.). Understanding the language classroom. Basingstoke: Palgrave Macmillan, (2006).

FALCHIKOV, N. Improving Assessment through Student Involvement. London: Routledge Falmer, 2005.

FEEDBACK, D.R., WHITE PAPER Engaging Students in the Writing Process with Turnitin. Available in: <https://turnitin.com/static/resources/documentation/turnitin/company/Turnitin Whitepaper_Writing_Process.pdf $>$ Accessed on February 29, 2012.

FRY, H., KETTERIDGE, S., \& MARSHALL, S. A Handbook for Teaching and Learning in Higher Education: Enhancing academic practice. 3rd Ed. Oxon: Taylor \& Francis, 2009.

MILLER, I.K. 'Puzzle-driven' language teacher development: The contribution of Exploratory Practice. In T. Yoshida, H. Imai, Y. Nakata, A. Tajino, O. Takeuchi, \& K. Tamei (Eds.). Researching language teaching and learning. An integration of practice and theory. Bern: Peter Lang, 2009, p. 77-93.

NICOL, D.J. \& MACFARLANE-DICK, D. Formative assessment and self-regulated learning: a model and seven principles of good feedback practice. Studies in Higher Education, 31(2), (2006), 199-218. Available at: http://www.tandfonline.com/doi/ abs/10.1080/03075070600572090. Accessed on February 29, 2012.

RAMSDEN, P. Learning to Teach in Higher Education. $2^{\text {nd }}$ ed. Abingdon: Routledge Falmer, 2003.

SADLER, D. R. Formative assessment: revisiting the territory. Assessment in Education, 5(1), 1989, p. 77-84. 


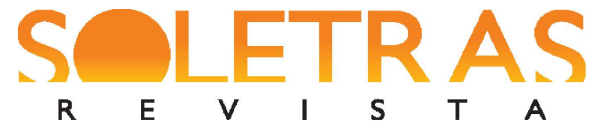

DOSSIÊ-N. 35 - 2018.1 - ANABEL GUTIERREZ ASSIA SLIMANI-ROLLS CHRIS ROWELL

SLIMANI-ROLLS, A., \& KIELY, R. Exploratory Practice for Continuing Professional Development. An innovative Approach for Language Teachers. London: Palgrave Macmillan, 2018.

SLIMANI-ROLLS, A., \& KIELY, K. 'We are the change we seek': developing teachers' understanding of their classroom practice. Innovations in education and Teaching International. Routledge Taylor \& Francis Group. Vol.51, No.4, 2014, p. 425-435.

SLIMANI, A. Evaluation of Classroom Interaction. In: ALDERSON, J.C., \& C. Beretta (eds.). Evaluating Second Language Acquisition. Cambridge: Cambridge University Press, 1992, p. 197-220.

STEFANI, L.A.J. Assessment in partnership with learners. Assessment and Evaluation in Higher Education. 23(4), 1998, p. 339-350.

\section{Avaliação como processo de aprendizagem: o uso da Prática Exploratória para empoderar alunos e para promover o desenvolvimento do professor}

O presente artigo tem dois objetivos. O primeiro deles uma pesquisa longitudinal desenvolvida por um ano (2016-2017) que reporta a configuração e a implementação de um módulo de avaliação através do processo de revisão pelo colega (BOSTOCK, 2000; TOPPING, 2000; FALCHIKOV, 2005) usando Turnitin, um serviço comercial para detecção de plágio baseado em dados da internet. A revisão pelo colega tem por objetivo ajudar os alunos a entenderem os critérios de atribuição de notas e os padrões, os quais recebem atenção durante/no desenvolvimento das habilidades de pesquisa, e os encoraja a assumirem o controle de seu aprendizado. Os processos de revisão pelo colega representam o feedback formativo que os aprendizes oferecem uns aos outros de forma a possibilitar atingir o padrão que seus trabalhos precisam basicamente atingir antes da submissão final. Por outro lado, o artigo também destaca as questões de desenvolvimento profissional que emergiram como consequência da adoção da abordagem ancorada em princípios da Prática Exploratória (PE) (ALLWRIGHT 2003, 2005; GIEVE \& MILLER, 2006; ALLWRIGHT \& HANKS, 2009), a qual permitiu à professora e aos alunos trabalharem por uma melhor qualidade de vida, enquanto aprofundavam seus entendimentos em relação ao que estavam tentando atingir juntos em sala de aula. Vários benefícios foram identificados como resultado da investigação. Os alunos conseguiram uma melhor compreensão dos procedimentos de revisão da literatura, aumentaram sua motivação para aprender sobre os tópicos que precisavam investigar, engajaram-se mais profundamente nas atividades durante as aulas e parecem ter se apropriado de sua própria aprendizagem. A própria professora expressa sua reflexão sobre os benefícios advindos de trabalhar colaborativamente com seus alunos e com especialistas das áreas relacionadas, bem como descobre que o processo gerou insights que transformaram sua prática docente de várias maneiras.

Palavras-chave: Prática exploratória. Desenvolvimento pessoal do professor. Teste formativo. Revisão por pares. Alunos autorregulados.

Recebido em: 14 de abril de 2018.

Aprovado em: 29 de abril de 2018. 